한국항해항만학회지 제 37 권 제 6 호

J. Navig. Port Res. Vol. 37, No. 6 : 627-635, December 2013 (ISSN:1598-5725(Print)/ISSN:2093-8470(Online))

DOI : http://dx.doi.org/10.5394/KINPR.2013.37.6.627

$$
\begin{gathered}
\text { 해항도시의 경제성장과 해양산업 간의 관계 } \\
- \text { 부산시를 중심으로 - } \\
\text { 강윤호* }+ \text { 우양호 } \\
\text { * 한국해양대학교 해양행정학과 교수, }+ \text { 한국해양대학교 국제해양문제연구소 } \mathrm{HK} \text { 교수 }
\end{gathered}
$$

\title{
The Relationship between Economic Growth of Sea Port City and Ocean Industries: Focused on Busan Metropolitan City
}

\author{
Yunho Kang ${ }^{*} \cdot+$ Yang-Ho Woo \\ * Professor, Korea Maritime and Ocean University, , Busan 606-791, Korea \\ + HK Professor, Korea Maritime and Ocean University, , Busan 606-791, Korea
}

\begin{abstract}
요 약 : 본 연구의 주제는 우리나라 제 1 의 항만이자, 해양수도인 부산시를 대상으로 해항도시(sea port city)의 경제성장에 영향을 미치는 해양산업(ocean industries)의 장기적인 효과 및 그 주요 요인을 분석하는 것이다. 즉 수산업, 해운항만산업, 해양관광산업, 조선업 등 해항도 시의 다양한 해양산업이 그 도시의 경제성장에 어떠한 영향을 미치는 지를 부산시를 대상으로 심층 연구한다. 이를 위해 해항도시의 경제성 장과 각 영향변인들에 관한 논거를 살펴보고, 다시 이를 토대로 수산, 해운항만, 조선, 해양관광, 도시재정, 인구, 정치 등에 관한 변수를 설정 하여 연구를 수행하였다. 주요 연구결과는 다음과 같다. 첫째, 해항도시 부산의 사례에서 해양산업이 도시의 경제성장에 미치는 효과는 상당 한 수준으로 나타났다. 둘째, 수산업, 해운항만산업, 조선산업, 해양관광산업 등 연구대상으로 삼은 모든 분야의 해양산업이 해항도시의 경제 성장에 영향을 미치는 것으로 나타났다. 단, 도시경제성장에 대해 해운항만산업과 해양관광산업 및 조선산업의 활성화는 긍정적인 영향을 미 치는데 반해, 수산업의 활성화는 부정적인 영향을 미치는 것으로 나타났다. 이러한 점들은 우리에게 해항도시에 대한 해양산업의 경제적 기여 를 새롭게 인식하도록 만드는 동시에, 향후 정부가 해양산업에 관한 주요 성장동인을 발견할 수 있도록 하는 여러 정책적 시사점을 제공하였 다.
\end{abstract}

핵심용어 : 경제성장, 해항도시, 해양산업, 변인, 부산광역시

Abstract : This study examines the issue of causality between ocean industries and urban economic growth in the sea port city. To maximize economic advantage of Busan as a sea port city, we first need to analyze the effects of ocean industries on urban economic growth. This study focuses on the examination of the role of ocean industries and its related variations in economic growth at the urban level. Using data from Busan. Metropolitan City in Korea during 1985-2011, we find that the causality link between ocean industries and urban economic growth rates runs in both directions. Especially, industries of shipping/port, marine tourism, and shipbuilding were the most important variables in Busan economy. With this information, the empirical results show that ocean industries and its related variations have significant effects on urban economic growth. Based on these significant research findings, theoretical and practical implications were discussed.

Key words : urban economic growth, sea port city, ocean industries, variable, Busan Metropolitan City

\section{1. 서 론}

일반적으로 각 지역의 경제성장은 그 지역만의 특수한 산 업이나 구조에 큰 영향을 받으며, 지정학적으로 내륙과 해양 에 위치한 도시는 큰 차이를 보인다. 이에 각 지역의 특화 산 업이 그 지역의 경제성장에 어느 정도 영향을 미치는 지를 분 석하는 것은 대단히 큰 의미가 있을 것으로 보인다. 그리고
이와 같은 관점에서 보면, 특히 바다에 인접해 있는 해항도시 (sea port city)의 경우에 독특한 해양산업의 특성이나 그 구 조가 그 도시의 경제성장에 미치는 영향을 분석하는 것은 학 문적으로 일정한 의미를 지니게 될 것이다.

본 연구는 부산시를 대상으로 하여 해항도시의 해양산업과 그 구조가 도시의 경제성장에 미치는 영향을 분석하는 것을 목적으로 하고 있다. 분석사례로서 우리나라 대표적 해항도시

\footnotetext{
* Primary author : 연회원, yhkang@kmou.ac.kr 051) 410-4732

† Corresponding author : 연회원, woo8425@hanmail.net 051) 410-5265

(주) 이 논문은 한국해양대학교 국제해양문제연구소 인문한국(HK)지원사업의 공동연구이며, 사사표기는 뒤쪽(후기)에 기재되었음. 이 논문은 2013년 서울행정학회 추계 국제학술대회(2013. 10. 25)에서 공동으로 발표된 논문을 수정 및 보완한 것임.
} 
인 부산의 해양산업과 도시경제를 다룬다. 부산의 지역경제는 1970년대까지 한국 경제의 중심적 위치에 있었으나, 1980년대 이후부터 최근까지는 절대적 성장에도 불구하고 타 시·도에 비하여 상대적으로 계속 침체되는 경향을 보이고 있다.

따라서 해항도시 부산의 지역경제성장에 대한 영향요인을 새로운 성장동력인 해양산업을 중심으로 분석하는 것은, 향후 부산 지역경제의 활성화를 위한 해양정책의 방향을 가늠하게 해주고, 여러 정책적 시사점을 찾는 데에도 중요한 의의를 지 닐 수 있을 것으로 보인다. 또한 그것은 부산 지역뿐만 아니 라 여건이 비슷한 여타 해항도시의 경제 활성화 대책에도 유 용한 시사점을 제공해 줄 수 있을 것으로 보인다.

이와 같은 관점에서 분석된 기존 연구로는 항만을 중심으 로 하여 항만이 해항도시(海港都市)의 경제성장에 미치는 영 향을 분석한 $\mathrm{WoO}(2009)$ 의 연구를 들 수 있다. 그러나 본 연구 에서는 항만뿐만 아니라 해운업, 수산업, 해양관광산업, 조선 산업 등 해항도시의 보다 다양한 해양산업이 그 도시의 경제 성장에 어떠한 영향을 미치는 지를 부산시를 대상으로 해서 심층적으로 연구하고자 한다. 즉 본 연구는 다양한 해양산업 과 해항도시의 경제성장의 관계에 대해 그간 다루어지지 않았 던 내용을 종합적으로 고려하여, 시계열 자료를 통해 해양산 업의 장기적인 도시경제 성장효과 및 그 성장요인을 경험적으 로 검증해 본다.

\section{2. 이론적 배경 및 선행연구의 검토}

\section{1 해양산업의 의의}

일반적으로 해양산업은 “해양을 이용, 개발 또는 보전, 보호 하는 모든 산업부문과 생산적 활동”을 총칭하는 개념이다. 외 국에서도 해양산업에 대한 일반적인 지칭은 광의의 의미로 사 용되는데, 해양산업(Ocean Industries, Marine Industries, Maritime Industries), 해양부문의 제반산업(Marine and Ocean Industries, Ocean Sector), 해양경제(Marine Economy, Ocean Economy) 등의 용어가 혼재되어 사용되고 있는 실정 이다. 현실적으로 해양산업(Ocean Industries)의 정의는 각 국 가별 실정과 상황에 따라 다르게 지정되어 있다. 해양선진국 의 사례만을 보자면, 먼저 미국의 경우 해양산업은 총 6 개 부 문에 23개 산업이 지정되어 있다. 세부적으로 해양생물자원산 업 부문에는 양식업/종묘생산업, 어업, 수산물가공, 수산물 유 통/판매업이 포함된다. 해양광업 부문에는 해사/골재 채취업, 해저 석유/가스 탐사 및 개발업이 포함된다. 조선업 부문에는 보트 건조 및 수리, 선박 건조 및 수리 등이 포함된다. 해양관 광업 부문에는 위락/레크레이션 서비스, 음식업, 숙박업, 마리 나산업, 캠핑장 운영, 해상경관 투어, 스포츠용품 판매업, 아쿠 아리움 등이 포함된다. 해운업에는 화물운송, 여객운송, 해상 운송 관련 서비스, 항해장비, 보관창고업이 포함된다. 해양건 설업에는 해양플랜트사업이 포함되어 있다(Kim \& Kee, 2005;
Woo, 2013).

영국의 경우, 해양산업은 해운업, 해양관광산업, 해저유전산 업(oil \& gas), 해산물(seafood) 가공, 해양장비, 어업, 조선업, 방위조선업, 항만업, 양식업, 레저보트조선업, 크루즈산업, 연 구개발 $(\mathrm{R} \& \mathrm{D})$ 사업, 해양서비스업, 해양에너지, 보안 및 통제, 해양조사, 교육훈련, 해저기술, 해저굴착장비 등의 20개 부문 에 대해 지정되어 있다. 호주의 경우, 해양산업은 해양관광산 업, 해양석유정제업, 수산 및 수산가공식품업, 해운업, 조선업, 항만업 등에 걸쳐 6개 산업이 지정이 되어 있다(Jung, 1999; Park, 1999). 국내의 해양산업은 전반적으로 초기단계에 있으 며, 첨단기술의 발전과 함께 발전이 가속화되고 있다. 해양산 업은 구체적으로 $\mathrm{U}$-기반 항만물류산업, 조선 · 조선기자재산 업, 물류 - 항만기술개발산업, 해양에너지개발산업, 해양바이오 산업, 해양안전 - 환경기술개발산업 등으로 분류할 수 있고, 이 러한 하위 해양산업들에 속하는 모든 기업체들을 해양산업체 라고 통칭하고 있다(Kim \& Kee, 2005; Woo, 2013).

지금 부산이 지향하는 해양수도(ocean capital)의 모습은 해 양을 중심으로 각종 경제, 사회, 문화적 활동이 활발한 도시를 의미하며, 특히 해양산업이 종합적으로 발달한 세계적인 도시 를 의미한다(Busan Metropolitan City, 2012). 이에 부산은 지 난 2009년 우리나라 최초로 “부산광역시 해양산업육성 조례 (부산광역시 공고 제2009-814호)”를 제정하여, 지역해양산업 을 체계적으로 육성·발전시키는 획기적인 정책근거를 마련 하였다. 이 조례는 해양산업의 정의와 범위를 규정하고 통계 관리를 의무화하기 위한 목적이 있다. 그리고 조례에서는 해 양산업을 해운·항만물류, 수산, 조선, 해양바이오, 해양과학기 술개발, 해양환경·방재, 해양관광, 해양레저·스포츠 및 해양정 보·금융 관련 산업 그 밖에 해양 및 해양자원의 관리·보전과 개발-이용에 관련된 산업으로 정의하고 있다. 따라서 제도적 으로 정의되는 해양산업이란, "생물공업, 해양광업, 해양에너 지산업, 해양토목 - 해양구조물산업과 같은 해양개발과 관련된 모든 산업"을 말한다(Marine Industry and Technology Organization, 2007).

Table 1 Classifying Criteria of Ocean Industries

\begin{tabular}{|c|c|c|c|c|}
\hline \multicolumn{3}{|r|}{ 기준(S: 공급, D: 수요) } & 예 & 본 연구 \\
\hline & S1 & 채집활동으로서의 경제활동 & 수산어 획 & 수산 \\
\hline & S2 & 해양공간을 활용하는 공간활동 & 수상운송 & 해운항만 \\
\hline \multirow[b]{2}{*}{ D1 } & D11 & $\begin{array}{c}\text { 해양생산물을 투입물로하는 } \\
\text { 생산활동 }\end{array}$ & $\begin{array}{l}\text { 수산통조림 } \\
\text { 제조업 }\end{array}$ & 수산 \\
\hline & D12 & $\begin{array}{c}\text { 해양에서의 경제활동을 위한 } \\
\text { 것으로 해양생물 외를 } \\
\text { 투입요소로하는 생산활동 }\end{array}$ & $\begin{array}{l}\text { 선박 } \\
\text { 제조업 }\end{array}$ & 조선 \\
\hline & D2 & $\begin{array}{c}\text { 지리적 측면으로 해양에 가까운 } \\
\text { 지역내에서의 경제활동 }\end{array}$ & $\begin{array}{l}\text { 해양레크레 } \\
\text { 이션 }\end{array}$ & 해양관광 \\
\hline
\end{tabular}

학술적으로는 해양산업의 구체적인 선정기준으로 흔히 Pontecorvo(1980)의 기준을 활용하고 있다. 그의 기준은 Table 1 과 같다. Table 1 에서 해양산업의 구별기준은 크게 공 
급측면 $(\mathrm{S})$ 과 수요측면 $(\mathrm{D})$ 으로 구분된다. 공급측면은 "해양이 경제주체에게 무엇인가를 공급해주는 것에 기초한 활동"을 의 미하는데, 2 가지 측면으로 구성되어 있다. 수요측면은 “경제주 체가 해양에 대해 무엇인가 수요를 지니는 경제활동”을 말하 는데, 3 가지 측면으로 구분되어있다. 이 기준은 1983 년도 UN 에서 해양산업 선정기준으로 선정된 바가 있을 정도로 해양산 업의 선정기준으로 널리 활용되고 있다. Table 1 의 각 측면에 해당되는 해양산업 부분은 상당히 많을 수 있지만, 현실적으 로 하나의 논문에서 모든 분야를 다 포괄하여 연구하는 것은 거의 불가능에 가까우므로, 분석사례인 부산시의 배경 및 연 구자의 가치에 따라 중요한 부문을 선택하여 연구할 수밖에 없는 한계가 있다. 본 연구에서는 앞에서 살펴본 부산광역시 해양산업육성 조례에서 정의하는 부산시의 해양산업 부문들 중에서 Table 1 의 각 측면에 해당될 수 있는 대표적인 것들을 골라서, 수산, 해운항만, 해양관광, 조선 등 4 가지 부문을 해양 산업 구성부문으로 설정하고 연구를 진행하였다.

\section{2 해항도시 경제성장과 해양산업}

경제성장은 "산출물의 총가치의 증가 또는 총소득의 증가" 로 정의될 수 있다(O'Sullivan, 2003). 따라서 도시경제의 성 장은 "특정 도시가 가진 산출물의 총가치 증가나 총소득 증 가"로 정의될 수 있을 것이다. 그리고 이러한 개념에 근거한 지역경제성장 이론은 접근방법에 따라 다양하게 분류될 수 있 다. 즉 수요에 중점을 두는 경제기반이론, 지역의 규모가 중요 한 것으로 보는 이론, 산업구조를 성장요인으로 보는 이론, 도 시체계에 초점을 두는 중심지 이론 등이 있다(Jeon, 2001).

한편, Clark(1940)와 Fisher(1933)의 경제발전단계설에 의하 면, 경제발전은 1 차 산업, 2 차 산업, 3 차 산업의 단계적 성장에 의하여 이루어지며, 지역성장이 진행되어감에 따라 지역산업 의 중요성(개별 산업 고용수/전체 산업 고용수)이 1 차 산업에 서 2차 산업으로, 2 차 산업에서 3 차 산업으로 이전해가며, 그 에 따라 소득의 증가도 크게 나타난다. 이와 같은 이론에 따 르면, 산업구조의 고도화나 변화는 지역경제의 성장에 영향을 미칠 것으로 보인다. 그동안 경제학자나 행정학자들에 의해서 산업구조의 고도화가 부가가치의 창출력을 높이고 지역경제 성장을 초래한다는 몇몇 연구가 있었다(Hwang, 1982; Park, 1993; Choi, 1995). 그러나 해운항만, 수산, 해양관광, 조선 등 해양산업구조의 변화와 해항도시의 지역경제성장 간의 인과 관계를 분석한 연구는 찾아보기 힘들다.

항만도시에서 항만과 경제성장에 관한 기존 연구들을 살펴 보면, 우선 연구의 초기에는 항만과 항만 및 항만과 배후부지 간의 연결에 초점을 두어 항만과 배후지역의 교통망의 변화에 따른 도시성장에 초점을 두고 연구가 수행되었다(Bird, 1963; Thompson, 1981; Hoyle, 1983). 이들은 이후에 컨테이너의 등 장과 더불어 컨테이너항만화에 따른 도시경제성장 단계의 유 형을 제시하였는데, 최근으로 올수록 항만과 배후부지의 관계, 항만과 항만 사이의 보완적 관계 등을 해항도시의 경제성장을
이끄는 요인으로 밝히고 있다(Graf, 2009).

이와 같이 항만환경이나 산업의 변화와 도시성장간의 직접 적 관계를 검증한 연구는 찾아보기 어렵다. 해양산업과 해항 도시의 경제성장 간의 관계와 관련하여, 항만산업 및 항만환 경과 지역경제성장을 분석한 연구는 $\mathrm{Woo}(2009)$ 에 의해 수행 되었다. 그의 연구는 부산과 인천을 대상으로 하여 항만이 해 항도시의 경제성장에 미치는 효과를 실증적으로 검증하였다. 그러한 연구의 결과로 항만시설 규모, 항만 물동량 규모, 그리 고 항만산업 매출액 총계가 해항도시의 경제성장에 긍정적 영 향을 미치는 것으로 나타났다.

그러나 해항도시의 주요 해양산업에는 해운항만산업 뿐만 아니라 수산업, 해양관광산업, 조선산업 등도 포함된다. 이런 점에서 보면 해항도시에서 수산업과 해양관광산업 및 조선산 업 등의 산업구조 변화와 지역 경제성장과의 인과관계를 분석 한 연구는 좀처럼 찾아보기 어렵다.

산업과 경제와의 관계에서 많이 연구된 것은 산업연관분석 기법을 이용한 연구들이 많다. 이와 같은 관점에서, 해양분야 에서는 Yoon(1991)이 산업연관분석기법을 이용하여 해양산업 의 국민경제적 파급효과를 분석하였다. 그의 분석결과에 따르 면, 우리나라 해양산업은 후방연쇄효과가 전방연쇄효과보다 매우 큰 것으로 나타났다. 후방연쇄효과가 큰 산업들은 끈.로 프·어망, 수산가공, 선박, 수상운동 부문으로 분석되었다.

다른 한편으로 그동안 해양산업 및 해항도시의 주제와는 다소 무관하지만, 일반적 관점에서 사회·경제·재정적 요인들 과 지역경제성장간의 인과관계에 관한 연구들이 많이 수행되 어왔다. 이들 연구에서 분석된 지역경제성장에 영향을 미치는 주요 변수들로는 인구규모, 노동참여율, 산업구조, 입지조건, 지방정부의 재정력 등을 들 수 있다(Park, 1993; Baek, 2004). Kang(2008)은 사회·경제·재정적 요인들 외에 정치·행정적 요 인들이 지역경제성장의 중요한 영향요인이 될 수 있다는 점에 착안하여, 선거, 지방자치제 실시 등의 정치·행정적 변수와 지 역경제성장 간의 관계를 분석하였다. 그 결과는 지방자치제 실시가 지역경제성장의 주요 결정요인이라는 것을 보여 주고 있다. 이상과 같은 기존의 관련 연구들에 비추어 보면, 본 연 구는 그동안 연구가 거의 없었던 해운항만, 수산, 해양관광, 조선 등을 중심으로 한 해양산업구조의 변화와 지역경제성장 과의 직접적 인과관계를 분석하고자 한다는 측면에서 의의가 있다.

\section{3. 연구설계}

\section{1 분석모형과 방법}

본 연구는 해양산업 및 해양산업구조와 해항도시의 경제성 장 간의 인과관계를 분석하므로, 해항도시의 경제성장이 종속 변수가 되며 해양산업 및 산업구조와 관련된 변수들이 독립변 수가 된다.

본 연구에서 이들 독립변수들과 종속변수간의 인과관계는 
회귀분석을 통해 검증이 이루어졌다. 구체적으로 회귀방정식 의 구성은 $\mathrm{Y}=$ 지역경제성장, $\mathrm{X} 1=$ 어가인구 규모, $\mathrm{X} 2=$ =수산물어 획고, X3=수산제조품생산고, $\mathrm{X} 4=$ 선박등록 규모, X5=항만물동 량 규모, $\mathrm{X} 6=$ 해양관광객 규모, $\mathrm{X} 7=$ 선박건조업 규모, $\mathrm{X} 8=$ 재정 력, $\mathrm{X} 9=$ 경제활동참가율, $\mathrm{X} 10=$ 선거, $\mathrm{a}=$ 오차항 등으로 만들어 진다 $(\mathrm{Y}=\mathrm{b} 0+\mathrm{b} 1 \mathrm{X} 1+\mathrm{b} 2 \mathrm{X} 2+\mathrm{b} 3 \mathrm{X} 3+\mathrm{b} 4 \mathrm{X} 4+\mathrm{b} 5 \mathrm{X} 5+\mathrm{b} 6 \mathrm{X} 6+\mathrm{b} 7 \mathrm{X} 7+\mathrm{b} 8 \mathrm{X} 8$ $+b 9 X 9+b 10 X 10+a)$.

\section{1) 종속변수}

앞서 밝힌바와 같이 도시의 경제규모를 측정하는 가장 일 반적인 방법은 특정 도시에서 생산되는 산출물(재화와 서비 스)의 총가치나 특정 도시에서 취득된 총소득을 측정하는 것 이다. 결국 경제성장은 산출물의 총가치의 증가 또는 총소득 의 증가로 정의될 수 있다(O'Sullivan, 2003).1)

이와 같은 관점에서 보면, 도시정부의 경제성장의 측정지표 로 가장 적합한 것은 지역내총생산(GRDP: Gross Regional Domestic Product)으로 볼 수 있다. 앞선 선행연구의 논의에 서 언급된 모든 지역경제성장에 관한 실증분석들도 지역경제 성장의 측정지표로 GPDP를 활용하였다. McDonald(2007)는 도시지역을 대상으로 연구하여 $\mathrm{GRDP}$ 를 도시의 경제성장의 측정지표로 삼고 있다.

본 연구의 회귀모형에 포함된 변수들의 측정지표는 Table 2 와 같이 구성되었다. 종속변수인 도시경제성장은 대부분의 선행연구들과 마찬가지로 지역내총생산 $(\mathrm{GRDP})$ 을 지표로 활 용하였는데, 물가상승률을 통제하기 위해 2005년도 기준으로 불변가격화된 자료를 활용하였다.

\section{2) 독립변수}

특정 산업분야의 규모나 활성화 정도를 대변해주는 변수에 는 해당분야의 종사자 수나 종사업체 수 등의 투입(input)변수 와 생산량이나 부가가치액 등의 산출(output)변수가 있다. 실 제 분석에서, 하나의 회귀모형에 투입될 수 있는 변수의 수에 는 한계가 있으며, 활용 가능한 자료의 수집이 불가능한 경우 가 많다. 따라서 본 연구에서는 각 해양산업 분야의 규모나 활성화 정도를 잘 대변해준다고 생각되는 투입변수와 산출변 수 중에서 중요성과 자료수집 가능성을 고려하여 회귀모형에 투입할 독립변수를 선정하였다.2)

해양산업에는 다양한 분야가 있을 수 있지만 본 연구에서 는 앞에서 언급하였듯이, 독립변수로서 해양산업 관련 변수는 크게 수산업, 해운항만산업, 해양관광산업, 조선산업 등 4 가지 분야의 변수들로 구성하였다. ${ }^{3)}$ 이 4 가지 해양산업 분야의 규
모나 활성화 정도를 나타내주는 변수에 초점을 두고, 앞에서 언급한 바와 같이 중요성과 자료 수집 가능성을 고려하여 다 음과 같은 변수들을 분석에 독립변수로 투입하였다.

즉 수산업 분야의 변수로는 어가인구(fishery population), 수산물어획고, 수산제조품생산고 등 3가지 변수의 규모를 사 용하였다. 어가인구는 수산업 분야의 종사자 규모를, 수산물어 획고는 수산활동의 결과를, 그리고 수산제조품생산고는 수산 물을 통조림 등으로 제조/전환시키는 수산 연관 산업의 규모 를 잘 대변해주는 변수로 볼 수 있다.

해운항만 산업 분야의 변수로는 선박등록과 항만물동량(컨 테이너수송량) 규모의 2개를 사용하였다. 선박의 등록규모는 해운항만산업 분야의 종사자 규모를 나타내주며, 컨테이너 물 동량은 해운항만산업의 활성화 정도를 가장 잘 대변해주는 변 수로 널리 활용되고 있다.

관광산업의 활성화 정도를 가장 잘 대변해주는 변수는 관 광객의 규모(수)이다. 따라서 해양관광산업 분야의 변수로는 해양관광객 규모를 사용하였다. 해양관광객의 규모는 부산의 대표적 해양관광지인 해수욕장과 태종대공원 이용자 수의 합 계를 사용하였다. 여행사 수, 숙박업체 수 등 관광산업 종사 규모를 나타내는 변수도 있을 수 있지만, 이들 변수는 해양관 광에만 특화되어 있지 않으므로 해양관광 산업의 규모를 대변 하는 변수로 활용하기는 어렵다.

조선산업 분야의 변수로는 선박건조업 규모(종사자 수)를 사용하였다. 선박건조업 종사자 수는 조선산업의 투입 규모를 잘 대변해주는 변수라고 볼 수 있다. 선박건조 수나 선박건조 업의 산출금액과 같이 조선업의 산출규모를 대변해줄 수 있는 자료는 현실적으로 수집이 불가능하여 활용하지 못하였다.

Table 2에서 보듯이, 해양산업 관련 독립변수 중 수산업 분 야의 어가인구 규모는 인구수(명)로, 수산물어획고는 수산물 어획량(톤)으로, 수산제조품생산고는 수산제조품수량(톤)으로 각각 지표화 시켰다. 해운항만 분야의 선박등록 규모는 등록 된 선박수(척)로, 항만물동량은 대표적인 물동량의 지표인 컨 테이너수송량(톤)으로 지표화 시켰다. 해양관광분야의 해양관 광객 규모는 부산의 대표적 해양관광지인 해수욕장과 태종대 공원의 이용자(입장객)수(명)를 지표로 사용하였다. 조선 분야 의 선박건조업 규모는 선박건조업 종사자 수(명)로 지표를 구 성하였다.

\section{3) 통제변수}

해양산업 관련 변수들의 도시경제성장에 대한 영향력의 크 기를 정확하게 분석하기 위해서는, 도시경제성장에 대한 제3

1) 제품 판매를 통한 수입(revenue)은 생산을 위한 투입요소를 제공한 사람들(노동자, 지주, 기업인, 자본소유자 등)에게 지불되기 때문 에, 생산의 총가치는 총소득과 동일하게 된다.

2) 현실적으로, 회귀분석 같은 하나의 통계분석 모형에 많은 변수를 투입하는 것은 불가능할 뿐만 아니라, 해양산업의 각 분야의 변수들에 대해 수집 가능한 시계열 자료는 많지 않은 실정이다. 따라서 분석에서 연구자의 판단에 의해 중요하다고 생각되며 자료수집이 가능한 변수들을 선별할 수밖에 없는 경우가 많다.

3) 해양산업의 부문이 이 4 가지로 설정한 이유는 2.1 해양산업의 정의 부분에 설명되어 있다. 
의 변수(허위변수나 혼란변수)의 종속변수에 대한 영향력을 통제하여야 한다. 즉 종속변수인 도시경제성장의 시계열적 변 화량은 해양산업 관련 변수의 영향을 받는 부분과 그 외의 제 3 의 변수에 의해 영향 받는 부분으로 구분될 수 있는데, 제 3 의 변수를 통제변수로 회귀모형에 투입함으로써 종속변수의 변 화량을 통제할 수 있고, 따라서 해양산업 관련 변수와 종속변 수간의 순수하고 더 정확한 인과관계를 파악할 수 있다. 따라 서 본 연구에서는 해양산업 관련 변수 외에 도시경제성장에 영향을 미칠 수 있는 제 3 의 변수들을 통제변수로 투입하였다. 통제변수로는 기존의 관련 이론과 선행연구들에 의해 지역경 제 성장에 영향을 미치는 변수로 많이 활용된 것들을 선택하 였는데, 재정적 변수로서 재정력, 경제적 변수로서 경제활동참 가율, 정치적 변수로서 선거를 사용하였다.

재정적 변수로서 도시정부의 재정력은 도시정부의 재정력 이 도시의 경제성장에 영향을 미칠 수 있다는 가설을 고려하 여 변수로 선택하였다. 도시정부의 재정력이 증대되면, 지방정 부가 재정적 자율성을 갖고서 다양한 지역개발 및 공공투자사 업을 수행할 가능성이 크므로, 도시경제의 성장 가능성이 높 아질 수 있다(Kang, 2008; Woo, 2009). 그리고 수 십년에 걸 쳐 비교적 급속한 성장패턴을 보인 부산과 같은 해항도시의 경우, 국가차원의 정치·경제적 이유 때문에 항만과 교역을 성장시키기 위해 재정적 지원을 지속해 왔으며, 상대적으로 이들 도시가 농촌이나 다른 내륙도시들보다 많은 혜택을 받으 며 성장했다는 점이 중요하게 지적되고 있다(Slack, 2004).

경제적 변수로서 경제활동참가율은 지역 내의 생산활동 가 능 인구 중에서 실제 생산활동 참여 인구의 비중이 클수록, 지 역의 부가가치 규모가 증가할 가능성이 높기 때문에 영향변수 로 투입하였다. 도시지역 내의 인구 중에서 경제활동에 참여 율이 높으면 산출량이 증가할 가능성이 높아질 것이다(Baek, 2004).

정치적 경기순환론에 의하면, 득표동기가 강한 정치인은 선 거가 가까워지면 득표 극대화를 위해 실업율을 낮추고자 경기 활성화 정책을 추진하게 되어, 결국 경기의 변동을 초래하게 된다(Pred, 1980; Frey, 1997). 이 이론은 미국의 도시에서 정 치가들이 선거승리를 위해 확장정책을 사용하는 반면, 선거 후에는 경기와 물가상승을 억제하기 위해 긴축정책을 구사한 다는 현상에 착안한 것이다(Lineberry \& Sharkansky, 1971). 이렇듯 선거는 도시의 경제성장에 영향을 줄 수 있는 외부적 요인이 된다. 이와 같이 정치인들이 선거시기에 경제정책의 변화를 통해 경기에 변동을 초래하게 된다는 정치적 경기순환 론의 관점에서 보면, 선거가 도시경제성장에 영향을 미칠 가 능성이 있으므로, 많은 선행연구들이 정치적 변수로서 선거를 지역경제성장에 영향을 미치는 변수로 활용하였다(Kang, 2008).

이와 같은 통제변수의 지표구성에 대한 설명이 Table 2에 나타나 있다. 재정력은 대표적인 지방정부 재정력 지표인 지 방재정자립도를 활용하였다. 경제활동참가율은 통상적으로 활 용되는 바와 같이, 15 세 이상 비경제활동 인구 대비 15 세 이상
경제활동인구 비율(\%)을 지표로 활용하였다. 선거는 가변수 (dummy variable)를 사용하였는데, 대통령 선거, 국회의원 선 거, 지방 선거 등 3 가지 선거 실시 연도에는 1 의 값을, 나머지 연도에는 0 의 값을 각각 부여하였다.

Table 2 Variables and Indicators

\begin{tabular}{|c|c|c|c|c|c|}
\hline \multicolumn{2}{|c|}{ 변수 } & 분야 & 변수 & 지표 & 비고 \\
\hline \multicolumn{2}{|c|}{$\begin{array}{l}\text { 종속 } \\
\text { 변수 }\end{array}$} & $\begin{array}{l}\text { 도시 } \\
\text { 경제 }\end{array}$ & 도시경제성장 & $\mathrm{GRDP}$ (백만원) & 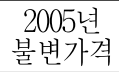 \\
\hline & \multirow{7}{*}{$\begin{array}{l}\text { 해양 } \\
\text { 산업 } \\
\text { 변수 }\end{array}$} & \multirow{3}{*}{ 수산 } & 어가인구규모 & 어가인구수(명) & \\
\hline & & & 수산물어획고 & 수산물어획량(톤) & \\
\hline & & & $\begin{array}{l}\text { 수산제조품 } \\
\text { 생산고 }\end{array}$ & 수산제조품수량(톤) & \\
\hline & & \multirow{2}{*}{ 해운 } & 선박등록규모 & 등록선박수(척) & \\
\hline & & & 항만물동량규모 & 컨테이너수송량(톤) & \\
\hline & & $\begin{array}{l}\text { 해ㅇㅑㅑ } \\
\text { 관광 }\end{array}$ & 해양관광객규모 & 해양관광지 이용자수(명) & $\begin{array}{c}\text { 해수욕장, } \\
\text { 태종대 }\end{array}$ \\
\hline & & 조선 & 선박건조업규모 & 선박건조업 종사자수(명) & \\
\hline & \multirow{3}{*}{$\begin{array}{l}\text { 통제 } \\
\text { 변수 }\end{array}$} & 재정 & 재정력 & 재정자립도 $(\%)$ & \\
\hline & & 경제 & 경제활동참가율 & $\begin{array}{c}15 \text { 세이상 } \\
\text { 경제 활동인구/15세이상 } \\
\text { 비경제활동인구×100(\%) }\end{array}$ & \\
\hline & & 정치 & 선거 & 선거실시연도 $=1$, 기타 $=0$ & $\begin{array}{l}\text { 가변수, } \\
\text { 대선·총선 } \\
\text { ·지방선거 }\end{array}$ \\
\hline
\end{tabular}

* Source: Busan Metropolitan City(1986-2012).

Korean Statistical Information Service(2012).

\section{2 연구대상}

본 연구는 부산광역시를 대상으로 한 사례분석이다. 부산광 역시는 우리나라의 가장 대표적인 최대의 해항도시(sea port city)이기 때문에, 도시경제성장이 해양산업과 밀접한 연관이 있을 것이므로 판단되므로, 해양산업 및 그 구조와 도시경제 성장 간의 인과관계를 분석하고자 하는 본 연구의 목적에 부 합하는 좋은 사례로 보인다.

본 연구는 시간적으로 1985년 이후 2011년까지의 시계열 자료를 통해 분석이 이루어졌다. 시간적 출발점을 1985년으로 정한 것은 해운항만 등 해양산업과 관련된 변수들에 대한 그 이전의 통계자료들은 수집이 특히 어려운 경우가 많았기 때문 이다. 또한 2013년 현재 시점에서 2012년 이후의 통계자료를 수집하는 것은 거의 불가능하기 때문에 2011년을 시간적으로 마지막 시점으로 하였다.

\section{4. 분석결과}

\section{1 지역경제와 해양산업의 추이와 실태}

Table 3에 부산시의 지역경제성장 및 해양산업의 추이가 나타나 있다. 부산광역시의 지역내총생산은 2005년 기준 불변 가격으로, 1985년 16,687,113백만원에서 꾸준히 성장하여 2011 년 55,877,675백만원으로 나타났다. 따라서 부산광역시의 지역 경제는 절대적 수준에서는 계속 성장하여 왔음을 알 수 있다. 
수산업과 관련하여, 어가인구는 1985년 12,480명에서 1990 년에 21,773 명까지 크게 증가하였으나, 이후 계속 감소하여 2011년 6,862명까지 감소하였다. 수산물어획고는 1985년 401,436톤에서 1995년 506,587톤까지 증가하였다가 다시 감소 세를 보여 2011년 433,452톤을 보여주고 있다. 따라서 1차 산 업으로서의 수산업(채취업)은 1990년대 초·중반까지 성장하 다가 그 이후 감소세를 보이고 있는 것으로 보인다.

수산제조품생산고는 1990년에 272,425톤까지 증가추세를 보이다, 이후 2000년 199,939톤까지 하락하는 추세를 보이더니 이후에 다시 증가추세를 보여서 2011년 525,151톤까지 대폭 증가하여 왔다. 수산업 중 채취된 수산물을 통조림 등의 상품 으로 제조/전환하는 산업의 규모는 시간의 흐름에 따라 변동 이 심하다는 것을 알 수 있다. 해운항만산업과 관련하여, 선박 등록수는 1985년 1,327척에서 1995년 1,724척까지 증가하였다 가 그 이후 약간 감소하여 2011년 1,681척으로 변화되었다. 그 러나 그 감소량은 미미한 정도에 그친다. 컨테이너수송량은 1985년 20,934,752톤에서 대폭적으로 계속 증가하여 2011년 $162,495,552$ 톤을 기록하고 있다. 따라서 해운항만산업은 계속 적으로 큰 증가세를 보여왔다고 볼 수 있다. 해양관광산업과 관련하여, 해양관광객 수는 1985년 12,508,967명에서 대폭적으 로 증가추세를 보이다 2000년 19,921,814명으로 잠시 감소하였 지만, 이후 다시 대폭 증가하여 2011년 36,323,273명으로 조사 되었다. 따라서 해양관광산업은 시간의 흐름에 따라 전반적으 로 큰 증가세를 보여왔다고 볼 수 있겠다. 선박건조업 종사자 수는 1993년 5,088명에서 시간의 흐름에 따라 등락을 거듭하 다가 2011년 5,408명으로 나타났다. 즉 선박건조업 종사자의 규모는 시간의 흐름에 따라 변화가 있지만, 장기적으로는 큰 변화가 없는 것으로 분석되었다.

Table 3 Economic Growth and Ocean Industries of Busan Metropolitan City

\begin{tabular}{|c|c|c|c|c|c|c|}
\hline 항목/연도 & 1985 & 1990 & 1995 & 2000 & 2005 & 2011 \\
\hline $\begin{array}{c}\text { 도시경제성장 } \\
\text { (GRDP) }\end{array}$ & $16,687,113$ & $26,550,779$ & $37,323,586$ & $39,276,954$ & $48,068,574$ & $55,877,675$ \\
\hline 어가인구 & 12,480 & 21,773 & 19,694 & 12,968 & 10,800 & 6,862 \\
\hline 수산물어획고 & 401,436 & 483,839 & 506,587 & 432,703 & 376,191 & 433,452 \\
\hline $\begin{array}{c}\text { 수산제조품 } \\
\text { 생산고 }\end{array}$ & 222,290 & 272,425 & 232,317 & 199,939 & 310,035 & 525,151 \\
\hline 선박등록 & 1,327 & 1,541 & 1,756 & 1,724 & 1,560 & 1,681 \\
\hline $\begin{array}{c}\text { 항만물동량 } \\
\text { (컨테이너수 } \\
\text { 송량) }\end{array}$ & $20,934,752$ & $42,404,106$ & $55,854,540$ & $67,801,888$ & $91,818,100$ & $162,495,552$ \\
\hline 해양관광객 & $12,508,967$ & $16,935,441$ & $30,627,382$ & 19,921,814 & $37,015,877$ & $36,323,273$ \\
\hline 선박건조업 & - & 5,088 & 6,556 & 5,071 & 7,383 & 5,408 \\
\hline
\end{tabular}

주) 해양관광객수의 1985 년의 자료는 1987 년 기준 자료임. 선박건조 업종사자수의 1990 년의 자료는 1993 년 기준 자료임.

결국 부산광역시의 해양산업은 해운항만부문과 해양관광부 문은 시간의 흐름에 따라 계속하여 큰 성장세를 보여온 것으
로 보인다. 수산부문에서는 수산물을 직접 채취하는 1 차 산업 (어가인구, 수산물어획고) 관련 부문은 1990년대 초·중반까 지 성장하다 그 이후 감소추세를 보이고 있는 반면, 채취한 수 산물을 제조품으로 전환하는 2차 산업 관련 부문은 등락을 거 듭하다가 2000년대 이후에는 증가하는 추세를 보이고 있다. 조선 부문은 시간의 흐름에 따라 약간씩 등락을 거듭하는 수 준의 변화를 보이고 있다.

\section{2 지역경제와 해양산업 간 인과관계}

회귀분석을 통해 부산광역시의 지역경제성장에 대한 해양 산업 관련 변수들의 영향력을 분석한 결과가 Table 4에 나타 나 있다. $\mathrm{F}$-검정 결과 회귀모형은 유의수준 $\mathrm{a}=0.01$ 에서 유의 미한 것으로 나타났다( $\mathrm{F}$ 값=50.323). 결정계수(Adjusted $\left.\mathrm{R}^{2}=0.965\right)$ 를 통해 본 회귀모형의 설명력도 대단히 높아서, 본 모형의 독립변수들이 종속변수의 변화를 $96.5 \%$ 정도 설명해 주고 있음을 알 수 있다.

통상최소자승법의 회귀분석모형(OLS)이 충족 시켜야할 전 제와 관련하여, 본 모형에서 VIF값이 모두 9이하여서 다중공 선성의 문제는 없으며, Durbin-Watson값이 2.888이므로 자기 상관의 문제도 없는 것으로 보인다. 또한 회귀표준화 잔차에 대한 검토결과, 독립변수의 값에 대응한 종속변수 분포에서 등분산과 정규분포의 전제를 충족시키는 것으로 분석되었다.

$\mathrm{t}$-검정 결과, 어가인구 규모, 선박등록 규모, 항만물동량 규 모, 해양관광객 규모, 선박건조업 규모 등 5 개의 독립변수가 유의수준 $a=0.1$ 에서 종속변수인 도시경제성장에 유의미한 영 향을 미치는 것으로 분석되었다. 반면에, 독립변수 중에서 수 산물어획고와 수산제조품생산고의 2 개는 도시경제성장에 유 의미한 영향을 미치지 못하는 것으로 분석되었다. 지방재정력, 경제활동참가율, 선거 등 3 개의 통제변수는 모두 본 회귀모형 에서는 도시경제성장에 유의미한 영향을 미치지 못하는 것으 로 나타났다.

어가인구 규모의 종속변수에 대한 영향력은 부(-)로 나타 났다. 즉 어민의 숫자가 적을수록 도시경제성장이 커진다는 것이다. 이것은 부산지역에서 1 차 산업인 수산업이 사양화되 는 과정에서 자연스럽게 어민의 수가 감소하고, 산업구조가 3 차 산업 중심으로 고도화되는 과정에서 도시경제가 성장하면 서 나타난 현상을 반영한 결과로 보인다.

선박등록 규모와 항만물동량 규모가 도시경제성장에 정 $(+)$ 의 영향을 미치는 것으로 분석되었다. 이와 같은 결과는 등록 된 선박의 척수가 증가하고 항만의 물동량이 증가할수록 도시 의 경제성장률이 커진다는 것을 의미한다. 해양관광객 규모는 종속변수에 정 $(+)$ 의 영향을 미치는 것으로 나타났는데, 이것 은 해양관광객수가 증가할수록 지역경제성장이 촉진된다는 것을 보여주는 결과이다. 선박건조업 규모는 종속변수가 정 (+)의 영향을 미치는 것으로 나타났다. 이러한 결과는 선박건 조업의 종사자수가 증가하여 당해 산업의 규모가 커질수록 도 
강윤호 · 우양호

시의 경제성장이 증가한다는 것을 의미한다.

표준화된 회귀계수의 크기(절대값)를 통해 독립변수들 간 에 종속변수에 대한 상대적 영향력의 크기를 비교해 볼 수 있 다. 해양산업 관련 변수들 중에서 부산의 도시경제성장에 미 치는 영향력은 어가인구 규모가 가장 크고, 이어서 항만물동 량 규모, 선박건조종사자 수, 해양관광객 규모, 해운선박등록 규모의 순으로 큰 것으로 나타났다.

어가인구 규모가 도시경제 성장에 가장 큰 영향을 미치는 결과는, 부산시의 산업구조가 3 차 산업 중심으로 고도화 되는 과정에서 1 차 산업으로서의 수산물 채취 종사자 수가 감소하 는 가운데, 도시의 부가가치액이 크게 증가 한 현상을 반영해 주는 것으로 보인다. 수산업 외의 나머지 해양산업 부문은 부 산시의 도시경제 성장에 긍정적인 영향을 미치는 것으로 분석 되었다. 따라서 해운항만, 해양관광, 조선 등의 산업분야의 활 성화는 부산시 경제성장을 촉진시키는 요인으로 볼 수 있을 것이다. 부산시의 경제성장에 긍정적 영향을 미치는 분야들 중에서는 해운항만산업이 가장 큰 영향을 미치며, 이어서 조 선산업, 해양관광산업의 순으로 영향력이 큰 것으로 분석되었 다.

Table 4 Ordinary Least Squares Regression of Variables

\begin{tabular}{|c|c|c|c|c|c|c|c|}
\hline & 회귀계수 & 표준오차 & $\begin{array}{l}\text { 표준 } \\
\text { 회귀 } \\
\text { 계수 }\end{array}$ & t값 & $\begin{array}{l}\text { 유의 } \\
\text { 확률 }\end{array}$ & VIF \\
\hline \multicolumn{2}{|r|}{ 상수 } & 6458166.6 & 40907427.8 & & 0.158 & 0.878 & \\
\hline \multirow{3}{*}{ 수산 } & 어가인구규모 & $-1067.0^{* * *}$ & 197.0 & -0.691 & -5.418 & 0.001 & 8.3 \\
\hline & 수산물어획고 & -2.8 & 9.1 & -0.030 & -0.303 & 0.769 & 5.0 \\
\hline & 수산제조품생산고 & 0.851 & 6.1 & 0.014 & 0.140 & 0.892 & 5.0 \\
\hline \multirow{2}{*}{ 해운항만 } & 선박등록규모 & $16895.8^{*}$ & 7842.3 & 0.206 & 2.154 & 0.063 & 4.7 \\
\hline & 항만물동량규모 & $0.086^{* *}$ & 0.03 & 0.315 & 2.684 & 0.028 & 7.0 \\
\hline 해양관광 & 해양관광객규모 & $0.2^{* *}$ & 0.1 & 0.221 & 2.451 & 0.040 & 4.2 \\
\hline 조선 & 선박건조업규모 & $2065.2^{* *}$ & 619.5 & 0.240 & 3.334 & 0.010 & 2.7 \\
\hline \multirow{3}{*}{ 통제변수 } & 지방재정력 & 41132.4 & 82439.4 & 0.061 & 0.499 & 0.631 & 7.6 \\
\hline & 경제활동참가율 & -71582.3 & 669217.7 & -0.013 & -0.107 & 0.917 & 7.2 \\
\hline & 선거 & 400547.0 & 895286.1 & 0.027 & 0.447 & 0.666 & 1.8 \\
\hline
\end{tabular}

\section{5. 결 론}

본 연구는 부산광역시를 대상으로 하여 해항도시의 해양산 업이 도시경제성장에 미치는 영향을 분석하는 것을 목적으로 하였다. 분석결과, 수산업, 해운항만산업, 해양관광산업, 조선 산업 등 분석대상이 된 모든 분야의 해양산업이 도시의 경제 성장에 영향을 미치는 것으로 나타났다. 단, 도시경제성장에 대해 해운항만산업, 해양관광산업 및 조선산업의 규모 증가나 활성화는 긍정적인 영향을 미치는데 반해, 수산업의 증가나 활성화는 부정적인 영향을 미치는 것으로 나타났다. 이들 도 시경제성장에 대한 산업 분야 간 상대적 영향력의 크기는 수 산업, 해운항만산업, 조선산업, 해양관광산업의 순으로 분석되
었다.

분석결과를 통해 부산시의 경제성장과 해양산업을 활성화 시키는 데 도움이 될 수 있는 다음과 같은 시사점을 얻을 수 있었다. 첫째, 해양산업 중에서 부산시의 경제성장에 가장 큰 긍정적인 영향을 미치는 분야는 해운항만산업인 것으로 분석 되었으므로, 부산시의 경제성장을 촉진시키기 위해서는 기존 부산항 및 부산신항만의 물동량을 증가시키고 선박등록을 촉 진시킬 수 있는 정책적 방안을 마련하여야 할 것이다. 이를 위해서는 기존 부산항 및 부산신항만이 국가항만으로서 중앙 정부와 부산항만공사가 항만개발과 운영의 책임을 지고 있으 므로, 부산시와 중앙정부가 협조하여 항만시설을 현대화시키 고 항만요율을 조정하는 등의 정책적 방안을 통해 싼 가격에 고품격의 항만 서비스를 제공할 수 있는 방안을 찾아야 할 것 으로 보인다.

둘째, 조선산업의 활성화도 부산시의 경제성장에 상당히 큰 영향을 미치고 있는 것으로 분석되었다. 따라서 조선업체를 시내로 유치할 수 있는 유인책을 강구할 뿐만 아니라, 조선 및 조선기자재 관련 연구에 대한 지원을 통해 조선 및 조선기자 재산업을 활성화시킬 수 있는 방안을 모색할 필요가 있을 것 으로 보인다.

셋째, 해양관광산업도 부산의 지역경제성장에 영향을 미치 고 있으므로, 해양관광산업 활성화 정책에 관심을 보일 필요 가 있다. 우선적으로는 해수욕장, 태종대 등 유명 해양관광지 의 서비스의 질을 높이고 주변의 숙박 및 교통시설의 개선 노 력이 요구된다. 또한 이들 기존의 유명 해양관광지 외에도 도 서관광, 해양체험 전시관 등 다양한 새로운 해양관광 상품을 개발할 수 있는 방안도 마련해야할 것으로 보인다.

넷째, 수산업과 관련하여 어가인구의 성장은 부산의 경제성 장에 부정적인 영향을 미치는 것으로 나타났다. 즉 수산물 채 취에 종사하는 어가인구의 수가 감소할수록 부산의 도시경제 는 성장한다는 결과를 말해준다. 이것은 부산에서 1 차 산업인 수산업(채취업)이 감소하고 2 차, 3 차 산업 중심으로 산업이 고 도화되면서 부가가치가 증가하는 현상을 설명해 주는 것으로 보인다. 그렇다고 하여 부산시의 경제성장을 위해, 어가인구의 규모 등 수산업을 인위적으로 축소시키는 것은 가능하지도, 바람직하지도 않다. 수산업의 활성화가 지역경제성장에 긍정 적인 영향을 줄 수 있는 구조를 창출해나가는 것이 중요할 것 이다. 산업구조가 점점 고도화됨에 따라 향후에도 점점 수산 업 종사자 수는 감소할 가능성이 큰 것으로 보인다. 이와 같 은 상황에서 수산업의 활성화를 지역경제 활성화 수단으로 만 들기 위해서, 부산시에서는 수산물에 기초한 해양 바이오산업 을 장려하거나 고부가가치를 창출할 수 있는 새로운 수산제품 브랜드의 개발 등을 적극 지원하는 정책을 마련하여야 할 것 이다.

다섯째, 부산지역의 경제성장을 위해서 해양산업을 활성화 시키되, 그 중 어느 분야에 더 큰 초점을 둘 것인지도 중요한 고려사항이 될 수 있다. 본 연구에 따르면 수산업을 제외한 해운항만, 조선, 해양관광 등의 대부분 해양산업분야가 도시경 
제성장에 긍정적인 영향을 미치는 것으로 분석되었으므로, 부 산시는 해양산업 분야 중에서 이들 긍정적 영향을 미치는 분 야의 산업 활성화에 우선적으로 정책적 우선 순위를 두어야 할 것으로 보인다. 이어서 수산 분야의 정책은 1 차 산업적 성 격의 수산물 채취에 대한 관심도 가지되, 채취된 수산물을 활 용한 2차 산업적 성격의 산업 개발에 주력할 필요가 있을 것 으로 보인다.

끝으로 본 연구는 일정한 한계를 지니고 있는데, 특히 활용 가능한 자료의 부재 혹은 자료수집의 어려움으로 인해, 분석 에 활용된 변수들의 시계열 자료가 많이 부족하였고 변수의 대표성에도 많은 문제를 지닐 수밖에 없었다. 또한 본 연구에 서 통제변수로 사용한 3가지 변수(지방재정력, 경제활동참가 율, 선거)의 종속변수에 대한 영향력이 통계적으로 유의미하 지 않게 나타난 점을 포함하여 통제변수의 선정 및 지표구성 등에 있어서 일부 한계가 불가피했었다는 점도 밝혀둔다.

\section{후 기}

이 논문은 2008년 정부(교육부)의 재원으로 한국연구재단의 지원을 받아 수행된 연구임(NRF-2008-361-B00001).

\section{References}

[1] Baek, W. H.(2004), "A Study on an Effective Financial Plan for the Growth of the Economy of the District of Busan", Ph. D Thesis, KyungSung University.

[2] Bird, J.(1963), The Major Seaports of the United Kingdom, London: Hutchinson.

[3] Busan Metropolitan City(1986-2012), Statistics in Busan.

[4] Busan Metropolitan City(1986-2012), White Paper.

[5] Busan Metropolitan City(1986-2012), Fifty-year History of the Korean Economy.

[6] Choi, Y. C.(1995), "Analysis of Regional Inequality in Economic Growth", Social Sciences Studies, Vol. 18, pp. $1-20$.

[7] Fisher, G. B.(1933), "Capital and the Growth of Knowledge", Economic Journal, Vol. 43, September, pp. 379-389.

[8] Frey, Bruno S. (1997). Political Business Cycles. Edward Elgar Publishing.

[9] Graf, A.(2009), Port Cities in Asia and Europe: Routledge Studies in the Modern History of Asia, Routledge.
[10] Hoyle, B.(1995), "Inter-Port Competition in Developing Countries: an East African Case Study", Journal of Transport Geography, Vol. 3, No. 2, pp. 87-103.

[11] Hwang, M. C.(1982), "Korean Regional Disparity and Regional Economies", Korea Research Institute for Human Settlements, Vol. 1, pp. 1-21.

[12] Jeon, D. I.(2001), Comprehension on local economy, Seoul: Kyo Woo Sa.

[13] Jung, B. M.(1999), "A Study on the Contribution of Port Industry to Korean Economy: An Input-Output Approaches", Journal of Korea Port Economic Association, Vol. 15. No. 2, pp. 1-14.

[14] Kang, Y. H.(2008), "An Analysis of Factors Influencing the Growth of Local Economies.", Korean Public Administration Review, Vol. 42, No. 1, pp. 365-381.

[15] Kim, A. H. and Kee, S. R.(2005), "Economic Effects of the Port Industries", Journal of Korea Port Economic Association, Vol. 21. No. 4, pp. 141-160.

[16] Korean Statistical Information Service(2013). http://kostat.go.kr.

[17] Lineberry, R. L. and Sharkansky, I.(1971). Urban Politics and Public Policy, New York: Harper \& Row, Publishers.

[18] Marine Industry and Technology Organization(2007), "A Study on Survey and Analysis of Marine Industry in Busan", Research Paper, pp. 1-35.

[19] McDonald, J. F.(2007), Urban America: Growth, Crisis, and Rebirth, M. E. Sharpe.

[20] O'Sullivan, A.(2003), Urban Economics, McGraw-Hill, Companies, Inc.

[21] Park, H. J.(1993), A Study on the Feasibility of Investment Programs by Local Governments, Korea Research Institute for Local Administration.

[22] Park, N, G.(1999). "A Study on the Location, Population Growth, and Cargo Concentration of Korean Port-Cities", Journal of Korea Port Economic Association, Vol. 17. No. 2, pp. 61-87.

[23] Pontecorvo, G.(1980), "Contribution of the Ocean Sector to the United States Economy," Science, Vol. 208, pp. 1000-1006.

[24] Pred, A. R.(1980), Urban Growth and City-Systems in the United States(1840-1860), Harvard University Press.

[25] Slack, B.(2004), Shipping and Ports in the Twenty-first Century: Globalization, Technical Change and the Environment(Ocean Management and Policy). Routledge. 
[26] Thompson, W. R.(1981), A Preface to Urban Economic and Public Policy, New York: St. Mantin's Press.

[27] Wang, J. J., Olivier, D., Notteboom, T. and Slack, B.(2007), Ports, Cities, and Global Supply Chains(Transport and Mobility), Ashgate Publishing.

[28] Woo, Y. H.(2010), "Sea Port and Urban Economic Growth: The Cases of Busan-Incheon, Korea(1985-2007)", The Korean Journal of Local Government Studies, Vol. 13. No. 3, pp. 339-362.

[29] Woo, Y. H.(2013), "Sea Port Cities and Globalization of Ocean Industries: Focusing on International Ocean Industry Exposition", Journal of Ocean Development, Vol. 22, pp. 65-94.

[30] Yoon, D. H.(1991), "Role of the Marine Sector in the Korean National Economy Using Input-Output Analysis", Ocean Policy Research, Vol. 6, No. 2, pp. 379-389.

원고접수일 : 2013년 7월 11일

심사완료일 : 2013년 10월 18일

원고채택일 : 2013년 11월 11일 